\title{
Communicating war in Mali, 2012: On-offline networked political agency in times of conflict
}

\section{ABSTRACT}

The Arab Spring raised high expectations for political freedom, especially for situations in which the rapid development of ICT intersects with political oppression and rebellion, as was the case in Mali, West Africa. In 2012 the country's northern part fell into the hands of 'rebels' and jihadists were on the rise. This article tries to understand the development of political agency in relation to the unprecedented access to new ICT of the Fulani nomads and urbanites in the Mopti region (Hayre), who engage increasingly with new actors and networks present in the war zone: 'rebels' and jihadists; the diaspora from that region; and the journalistic and academic communities who visit the region. We argue that political agency is emerging in the relation between (newly appearing) information networks in both the onand off-line worlds. These networked societies are embedded in cultural and social historical specificities of the Sudan-Sahel zone in conflict.

\section{KEYWORDS}

political agency networked social

spaces new ICTs social media Mali conflict 
1. For a description of the Fulani in the Hayre, see De Bruijn and Van Dijk (1995); for the Hayre diaspora, see Pelckmans (2011)

\section{INTRODUCTION}

The first news about the Mali conflict of 2012 came to us through telephonic communication with a person in Paris; second was the website of one of the main rebel 'movements' that led this war; and third were the phone calls we received from friends from the Northern Mali area. In a few weeks' time, Facebook pages where news on the situation was exchanged by people from Azawad, Bamako, the United States, Europe and the Malian diaspora elsewhere in Africa. In contrast, in the 1990s, a similar rebellion in Northern Mali did not have such exposure and there was hardly any communication with the outside world.

The central question for this article is how ICTs have influenced communication (frequency, but also content) about the conflict in Northern Mali and how these information flows have influenced the political communication and networks of actors in the region and beyond, influencing their room for political agency. This article focuses on communication in the 2012 period, which was the most intensive period of the war for the region of study, the Hayre, with its main city and market town Douentza (see Figure 1).

We concentrate on the position of the (semi)nomadic (cattle herding) Fulani and their diaspora, ${ }^{1}$ during 2012, i.e. the period when the northern

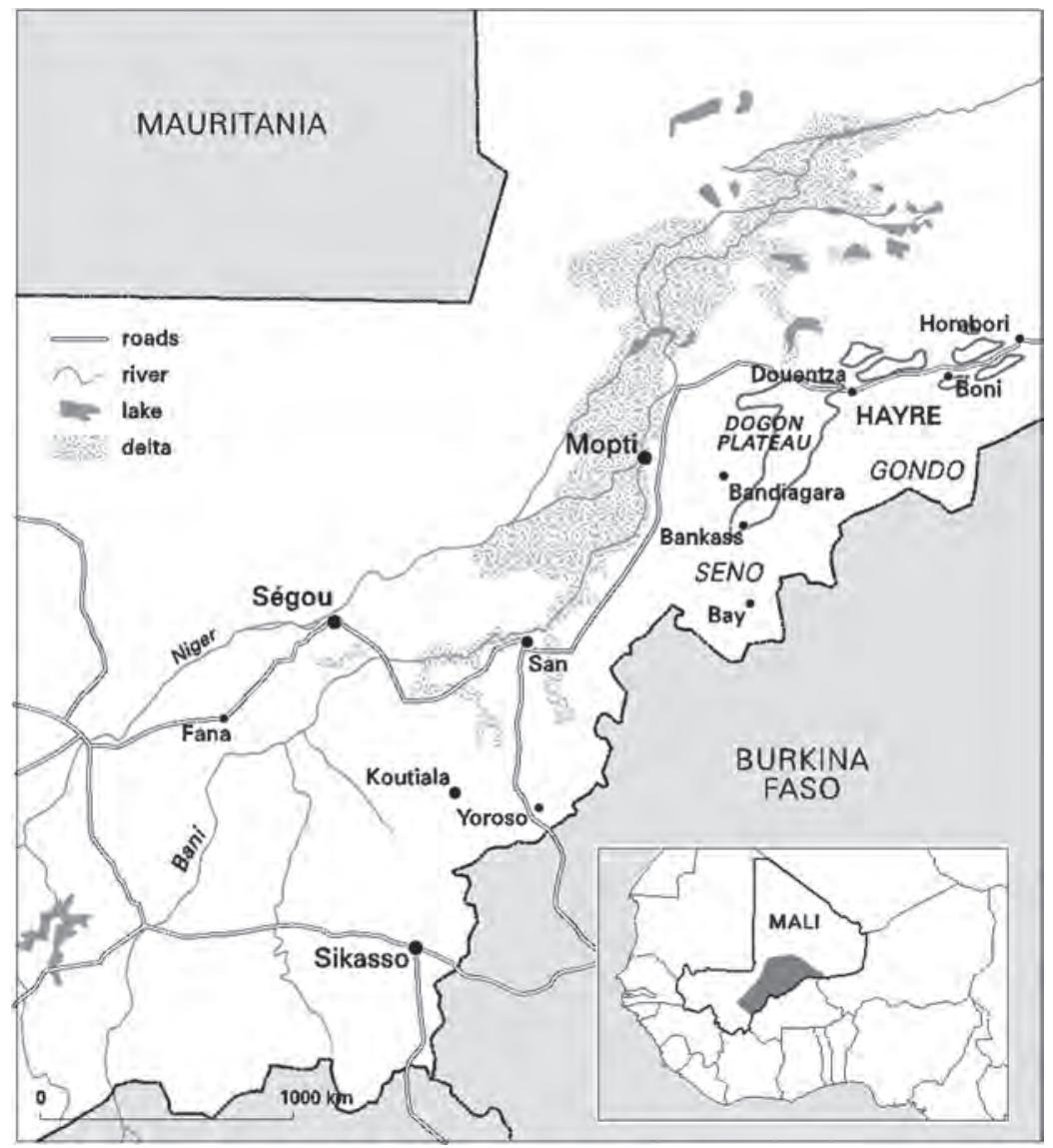

Figure 1: The Hayre area in the Mopti region of Central Mali. 
part of Mali was 'occupied' and had become a 'no-go area' for foreigners. We try to understand how these Fulani are linked to the different circuits of information that were created with the help of the new ICTs and how these different information circuits led them into new political networks and information and how this influenced their political agency both off- and online.

The interplay between new ICTs and the digitalization of communication (mobile telephony, Internet, social media) creates new social and political spaces, where (new) voices/actors can have a place and generate new (information and social) networks and political agency. With this empirical case study of Mali 2012 we contribute to a better understanding of this new political space, which is still a field to be explored (Georgiadou et al. 2013). The first studies in this field were based on case studies in the Western world, Latin America and the United States. These regions were the frontiers for Internet connectivity and access to social media. Rheingold's 2002 analysis of smart mobs is now a classic. Sub-Saharan Africa is only now, in 2014, more or less really connected. Communication is Power (Castells 2009). However, access to communication is not the same for everybody. The ability to act politically is related to rules of access that follow hierarchies and inequalities in society. Political agency is the space an individual can create to act politically and to develop ideas within these structural constraints (Chabal 2009). Such agency is now reformulated in the on- and off line spaces that new ICTs provide. Central to the discussion is how the on- and offline political spaces interact.

Although both off- and online communication can be digital, we distinguish between them as follows. With online communication, we mean here the interactional spaces that are created through written texts on internet forums (such as Facebook) that can be accessed on different technological devices (computer or smartphone). We distinguish this from off line communication, which is mediated by voice, gestures or face-to-face interaction. Although offline interaction is also supported by digital technology (a phone, for example), off line activity has a clear physical component (interactions through voice, gestures or movement). Offline communication is thus, for example, the radio, travelling and talking drums (see Gleick 2011). Of course both spaces also interact and Skype is a typical example of where offline face-to-face voice exchange is combined with online interaction of written chat messages. Increasingly, typical offline actions (voice communication, meetings) find their way into the online communities, and vice versa. It is in these spaces of interaction that we expect to find new dynamics of political agency.

A few studies have addressed the link between media and conflict for the case of Mali, but these mainly focus on the situation in Bamako. This is the case, for example, for the discussion on rumours and perceptions of the conflict by Gavelle et al. (2013) and the analysis of the role of media in the public debates following the coup in Bamako in 2012 by Hagberg and Körling (2012). This article focuses on the use of media on the ground in the war zone itself and connections between people in the field with the diaspora. In general, the Hayre can be considered relatively remote and disconnected in terms of modern communication, tarred roads, and other types of access to and from it. Since 2009, mobile telephony and Internet have become increasingly accessible in urban zones and in some rural areas. ${ }^{2}$ One of the (semi-) nomadic groups in the area, the Fulani, have a long history of networking and mobility, and as such they have always been strong in communication over space and in social networks (see de Bruijn 2007). The Mali conflict, which
2. See https:// mobileafricarevisited wordpress.com; Keita 2013a, 2013b; Ag Rissa 2009; Sangare 2009. 
3. The data we obtained resulted from our long-standing relationship with networks of people in and from the region. Mirjam de Bruijn has been working in the region since 1987 . Her main focus was on understanding Fulani society and the various ecological crises it underwent. After her M.A. research in 1987, she did her Ph.D. field research in 1990-1992, and her postdoctoral research in 1997, and has returned to the region for various research projects on a regular basis (in collaboration with Professor Han van Dijk). Lotte Pelckmans started her research in the region with sedentarized Fulani in 2001, which she expanded with Ph.D. research in 2005-2007 and with fieldwork among the Malian diaspora communities in France. Boukary Sangare did his M.A. thesis research in the region in 2009 and returned for a second Masters in 2012-2013. He began a Ph.D. project on the topic and region in the summer of 2014.

4. De Bruijn and Sangare 2012; Sangare 2012a, 2012b, 2012C; Pelckmans 2015.

5. One can think of the evolving descriptions of ethnographic research methods for online research; with mobile phones, see, for example, Pelckmans (2009); with the Internet, see, among others, Underberg and Zorn (2013), Horst and Miller (2012) and Hine (2000). manifested itself most strongly in 2012, inhibited mobility, introduced new actors in the region, and generated insecurity.

In this article we question where political agency emerges in the interaction between new ICT landscapes and war, such as in the case of Central Mali. Does the new political online space have offline effects (see Fahlenbrach et al. 2014a; de Bruijn et al. 2013)? What is the interplay between networked spaces, increased communication possibilities and war dynamics in this specific case? Do new political voices emerge? What role is played by the creation of the new or recent appearance of online space and visibility?

This article will not go into the details of the conflict and war in Mali but will outline the groups that provide or consume information with the help of new ICTs. This requires a short introduction to the changes in the Malian landscapes of media and politics. The next section will delve into the different information networks that circle around the nomads, and then we will relate our findings to some of the challenging ideas on the relation between ICT, networks, information flows and political agency from the literature. We will conclude with a discussion on the relation between ICT spaces and changes in political agency in warzone Mali, 2012.

\section{SETTING THE SCENE: THE HAYRE IN CONFLICT IN 2012 Researching political and social dynamics in Hayre's war year, 2012}

Having trust relationships has been crucial for our research in the region during this war period. Our long involvement in the region and the friendships we have developed made us develop such trust relations with our informants. ${ }^{3}$ We have all recently been to Mali for follow-up research: Mirjam visited Bamako in June 2012, and Lotte was in Bamako in February 2012, December 2013 and August 2014. Boukary undertook short field trips to the region while it was still occupied by militants in April and November 2012; he returned in August 2013 and again in August 2014, which resulted in several (online) publications about the conflict through the eyes of people living in the Douentza area (De Bruijn and Sangare 2012; Sangare 2012a, 2012b, 2012c). ${ }^{4}$

Our approach is qualitative. Through a deep understanding of and closeness to our main informants, we try to understand their ideas and moments of crucial decision making. These biographic data are contextualized with the help of interviews and (participant) observation data. We also include the virtual world as a research site, by following websites and Facebook groups with restricted access, and engaging in telephone conversations. ${ }^{5}$ We are therefore ourselves active agents in this online world. The division of work was related to the possibility of entering the region. Mirjam and Lotte as foreigners had to stick to working in the virtual realm and visiting Bamako. Boukary, as a Malian and Fulani, could go to the Hayre region several times and conducted interviews with informants of both Mirjam's and Lotte's networks.

\section{The advance of mobile telephony and the Internet}

Mali's capital, Bamako, was connected, at least theoretically, for the majority of its inhabitants through wireless technology in 2002. The interior received wireless technology only in 2006/2007. To be more specific, some of Northern Mali's towns have had connectivity since 2005/2006, while other smaller towns 
were connected from 2009 onwards. However, the bulk of surrounding rural areas was connected only in 2012/2013, when the 'occupation' of Northern Mali was a reality. National mobile phone coverage was a maximum of 30 per cent in 2009. We have no figures for later periods, but after 2009 we witnessed a high increase in the use of mobile phones among the people in the Hayre. In that period there was also a change in the technology of mobile telephony. Increasingly, people were opting for smartphones. This change in technology can be explained by the entrance of Chinese products into the market, la chinoiserie and also by the popularization of ICTs that was initiated by the Malian government from 2001 onwards. Initiatives to this end were the 'Centre Local d'Information et de Communication' (CLIC) and a so-called e-festival, 'Festival d'informatique dans les écoles'. Obviously, the policies of the main phone companies (Orange and Malitel) also contributed to facilitating access to the Internet through mobiles (mobile internet) and Live or fly boxes (with wifi networks). All these fairly recent developments allowed people in the North to use online networks like Facebook during the conflict.

\section{The war in the Hayre region ${ }^{6}$}

While the coup in Bamako took place in mid-March 2012 and the independence of Azawad territory was proclaimed on 6 April by the MNLA, ${ }^{7}$ it took this group until 13 May (1.5 months later) to formally install themselves in Douentza. They did so by occupying the control post at the entrance of the city and by surveying the station, the main road and the market. These are typically places that are central to communication, exchange and mobility in the town. According to some of our informants, the majority of the MNLA separatists who occupied Douentza are from native Tuareg factions of the area (coming from Bori and Kikara, which are villages in the region). Most of the MNLA rebels wore Malian army or police uniforms. ${ }^{8}$ Paate Tamboura, ${ }^{9}$ a young student originally from Boni, who is studying law at the University of Bamako, indicates how the MNLA was initially popular among other nomadic groups such as the Fulani:

Le MNLA has been very well received by the people ... On April 3d 2012, date of its first visit in Douentza. The MNLA has claimed the independence of Azawad on April 6th. The state was perceived negatively by the Fulbe nomads because of the multiple fees and taxes to which they have been forced to pay as victims of the agents of water and forestry and the gendarmerie. With the emergence of MNLA, they thought that Azawad would become a state par excellence for nomads and that this state would have measures favoring all aspects of nomad life.

However, the symbolic position of Douentza as the 'frontier of Azawad territory' lasted only 1.5 months. After that it turned into an ungoverned 'no-man's land'. Despite the media attention on the MNLA, the real threat came from several Islamist movements (Ansar Diine, MUJAO, and AQIM) who, on 26 June, chased the MNLA from Gao and became the new rulers of Northern Mali. ${ }^{10}$ Shortly afterwards, the MNLA also retreated from Douentza and left it empty of governmental agents: doctors, teachers, NGO personnel, prison guards and the city councillors, most of whom left for Bamako. ${ }^{11}$ The power vacuum in combination with an administrative void ${ }^{12}$
6. We will focus on the situation in the Hayre region without explaining in detail the causes and consequences of the crisis. For more on this, see Boas and Torheim (2013); ColdRavnkilde (2013); Lacher and Tull (2013); Lecoca et al. (2013); Boas (2012); and Lacher (2012).

7. The MNLA or Mouvement National pour la liberation de l'Azawad, is headed by freedom fighters and/ or separatists, mainly with Tuareg origins in the Kidal region.

8. See also Sangare (2013b), Figures 4 and 5. (http://www. connecting-intimes-of-duress.nl/ wp-content/uploads/ m\%C3\%AgmoireMaster-2-sociologieUCAD-BoukarySANGARE-080314.pdf).

9. Interview by Boukary Sangare with law student Paate Tambura in Boni (Douentza), 19 November 2012

10. See 'Mali: les islamistes contrôlent désormais la totalité du nord du pays', AFP Bamako, 11 July 2012, published on tv5 website: http:// www.tv5.org/cms/ chaine-francophone/ info/p-1911-norddu-mali-la-rebelliontouareg-en-deroutequitte-tombouctouhtm ?rub=6\&xml=news $\mathrm{m} / \mathrm{m}$ md. foe7ee1a46b7dboa 3fc7a7b8a57a6566.3e1. $\mathrm{xml}$.

11. Since many of the MNLA rebels are natives of Douentza region, they could easily flee and hide themselves in the 'bush'.

12. Administrative void because all governmental officers had fled and left the area early in April after its conquest by the MNLA. 
13. With the closure of schools, many pupils had to relocate to the South. The transitional government facilitated enrolment of students from the North in the South.

14. Sangare (2012C), Figure 14. (http:// www.ascleiden.nl/ content/douentzasous-occupation-desrebelles-du-mnlapremi\%C3\%A8res\%C3\%Agrie).

15. As in every other year, there have been violent confrontations between Fulbe and Dogon in the Douentza region. However, this year the violence and death toll has been exceptionally high. See for exemple "Nouveau bilan: 30 Burkinabés tués a la frontière avec le Mali dans des violences", 25 Mai 2012. http://www. maliweb.net/news/ faits-divers/2012/05/25/ article,69147.html.

16. De Bruijn \& Sangare (2012), p. 7: a bag of millet (100 kg) was sold in 2012 for 32,000 FCFA, which is twice as expensive as the usual 16,000 FCFA for the same product in the same month in 2011.

17. This is the Banque Internationale pour le Mali (BIM) à Douentza.

18. Mouvement pour l'Unicité et le Jihad en Afrique de l'Ouest (MUJAO).

19. The French military intervention Serval changed name and mandate in July 2014, and is now referred to as 'Barkhane'. plunged the Douentzankoobe (inhabitants of Douentza region) into dramas of all sorts: formal schooling stopped, ${ }^{13}$ medical care halted, and uncontrolled environmental degradation proceeded unchecked. ${ }^{14}$ The sick no longer had access to medicines, woodcutting went on uncontrolled, and the absence of administrators' mediation in land use conflicts probably explains this year's extremely high number of lethal conflicts. ${ }^{15}$ On top of that there were the food crisis and high inflation, with most prices doubling. ${ }^{16}$ Following the closure of the only bank, ${ }^{17}$ those families that relied on remittances could now only receive support through mobile phone transfers. In contrast to other Northern cities, once the MNLA retreated Douentza had not been immediately (re)occupied by either the Malian army or the Islamists; as a consequence, it literally became a political 'no-man's land' where neither the government nor the rebels had a say or claim for more than two months (between June and September 2012).

During this power vacuum, insecurity, for the nomads especially, was experienced as the problem par excellence in the area. The absence of any authority turned Douentza into a lawless, ungoverned no-man's land. Tensions between different ethnic groups (Fulbe, Dogon, Songhay, Tuareg) had become more intense and small arms were being traded in high quantities. The separatists from the MNLA were weakened by Islamists in other northern towns. After a period of at least two months of a complete power vacuum, Douentza was re-occupied by the sharia-inspired Islamist group $\mathrm{MUJAO}^{18}$ on 1 September 2012. In spite of a counter movement called Ganda Iso, consisting mainly of Fulani nomads with training received in Mopti from the Malian army, the Islamists of the MUJAO conquered them overnight. From September onwards, the MUJAO occupied the city. They gained people's trust by providing social services and security. Apparently, the Fulbe nomads from the area decided to send their children to the MUJAO training camps in the vicinity of Gao, informed by real concerns about security and economic survival rather than identification with Islamist ideologies.

The MUJAO left Douentza of their own accord when they heard about the French military intervention (Opération Serval) that would start end of 2012. Most of them disappeared with their four-wheel drives.

In what was presented internationally as the 'battle of re-conquest' of the North, all phone lines were cut for several days in order to smoothen Opération Serval. ${ }^{19}$ It was often only some days after the re-conquest of these cities that the GSM network was restored (see Keita 2013a). This confirms the significant role of monopolising communication (technologies) in war and conflict zones.

By the end of 2012 and the beginning of 2013 the Hayre had turned into a war zone, and to date new actors and networks are being installed. Apart from the nomads, the urbanites, Tuareg MNLA fighters, and MUJAO jihadists entered the scene, while government officials left the area and many inhabitants sought refuge in Mopti, Bamako, or Burkina Faso and Mauritania.

In the next section, we investigate how these different social and political circles used ICTs in their communication and organization, and how they became new information networks for the nomads and for outsiders. We also describe how these networks interacted with each other. The focus is, however, on where on- and offline distinctions blurred, since we suggest that in this complex dynamic new political agency would emerge. 


\section{NEW ICTS AND (DIS)CONNECTED COMMUNICATION/INFORMATION NETWORKS, 2012}

\section{Hayre networks and mobile telephony}

\section{Continuation in contacts ${ }^{20}$}

During the conflict, existing fears that phone masts would immediately be destroyed by rebels turned out to be false assumptions. In Douentza, many buildings and shops were looted and destroyed, but the phone masts remained intact and we were able to connect to our informants. Obviously, in the course of the conflict there were some minor cuts in the mobile phone connections. We heard about these occurrences in the surroundings of the small towns Ménaka, Goundam, Léré, and Diré shortly after they were conquered by the rebels. These cuts were collateral damage of the fighting but they never lasted long. Furthermore, none of the regional capital cities (Gao, Tombouctou, Mopti, and Kidal) or larger towns (such as Douentza and Gossi) of the northern regions suffered for more than two days from these cuts. When the French Opération Serval took off in January 2013, there were several moments in which phone networks were down. Those who could no longer join their family members in the North began to discuss on social media networks like Facebook about the possible causes and explanations for these cuts (see below).

The mobile phone had become an important tool for the inhabitants of the Hayre, as a provider of security, to maintain contact with people who had fled or were far away, and as a messaging device through which information entered and fed the discussions. The phone worked as a tool for security, for instance in ensuring the safety of the roads to the market. As underlined by Hamma Diallo, a nomadic pastoralist and cattle trader from Boni region, in November 2012 ${ }^{21}$ :

The mobile phone has come in very handy in this period of crisis. Thanks to the phone, we could contact our people, before travelling somewhere and making sure that everything is ok. If the rebels and/or bandits arrived somewhere, people take their phone in order to inform those who have travelled.

But probably the most important function of the mobile phone during the conflict was to keep people informed, be they friends and family who lived in Bamako or those living in other cities as emigrants or refugees. It was both for emotional contact and being informed about each other and for the practical reason of sending money to those in need. This role of migrants in the diaspora during the Mali conflict has been overlooked and will be touched on below (Gary-Tounkara 2013). The following quote by Boukary Tamboura (Fulbe diimaajo and technician of Radio Daande Douwansa), from November 2012, underlines this argument:

The fact that MNLA did not destruct the phone masts and mobile phone networks, was in their proper interest since they themselves cannot work without a phone network. This also worked to the advantage of the populations. Bamako, the capital city was informed in real time about all that takes place in Douentza by the occupants and as such the phone 'eased' the emigrants from the Douentza area who live elsewhere. They could call their parents and friends everyday to have news and know they were still there.
20. The information in this section is based on information gathered by Boukary Sangare, who went to the Hayre region in April 2012 and again in November 2012 (see Sangare 2010)

21. Interview by Boukary Sangare of Hamma Diallo, a Fulbe commercial trader, in Fetesambo, Boni area, Douentza province, November 2012. 
The phone provided information and images of the 'enemy' and/or different conflicting parties. At first, the PR machine of the separatist group MNLA managed to create a heroic image by posting YouTube films about their victories. Illiterate or not, people adored the content of these films. Even if they did not have Internet access or smartphones, it sufficed for one person to have downloaded the movies from the Net downtown, and then these movies were spread at a rapid pace among nomadic Fulbe thanks to Bluetooth technology. The Malian government did not have such convincing and short visual messages for the local populations of the North, and its communication strategies were therefore much less efficient (and manipulative?). The MUJAO (and the other militant movements) had clearly also developed communication strategies in which circulating videos and vodcasts (small films) of their victories through people's phones was central. For some groups (e.g., Fulbe in Douentza region), this contributed to their popularity and sometimes led to the Fulbe's adherence to the MUJAO (Sangare 2013b).

The first videos distributed in the region concerned the victories of the MNLA against the Malian army in the northern regions, clearly geared to highlight the heroic, not least in order to convince local populations that they had the capacity to conquer the North. After their defeat by MUJAO, it was the videos from Sharia-oriented Islamist groups such as the MUJAO that became prominent. Their videos had very anti-Western, anti-Malian and even anti-MNLA messages. In addition to the MUJAO, Ansar Diine also engaged in anti-MNLA and anti-Azawad slogans.

But it was not only this propaganda function that the mobile phone fulfilled. The MUJAO also used it to create and establish their power base in the Hayre. They connected to local populations through mobile phone. Boukary observed how MUJAO militants, upon their arrival in Douentza and Boni in September 2012, offered the locals access to their personal mobile phone numbers, which they could call in case they needed protection and/or assistance. Thus, behind a facade of the politics of war and fear, the MUJAO also invested in consolidation, peace and feelings of security. These had not been there even before the war. The Fulani nomads especially did not feel protected by the state, or secured. These observations from the Douentza region have also been reported from Timbuktu, where AQIM distributed phone numbers the local population could call in case of problems with bandits or members of the MNLA. This is part of the explanation as to why the Jihadists have been praised for their social services and work, such as bringing in expensive goods and distributing medicine and SIM cards to the poor. They also equipped local religious authorities with cars, money and weapons (Bøås and Torheim 2013).

Thus, mobile telephony enabled a continuation of contact between family, refugees and migrants. These networks also became linked to the information streams sent around by the population and the MUJAO or MNLA, thus creating a connection between ethnic groups in which networks based on family and friendships intermingled with information networks of the MUJAO and the MNLA. In terms of communication strategies, neither the state nor NGO circles were as successful in reaching out with online media to the Fulani nomads or to other villagers in the region. 


\section{Diasporas and Northern Mali}

Due to the marginalization and underdevelopment of this region, different ethnic groups from the Hayre have spread over large geographical spaces by emigrating to Equatorial Guinea, Libya, Europe and the United States. The influence of this diaspora cannot be underestimated. Some youth in the urban centres of the area (Boni, Douentza) have the means to access the Internet and partake in exchanges with migrants living far away.

An example is the Douentza Facebook group that made it possible for the youth that grew up in Douentza, but currently live outside of the area, to get to know each other, connect to each other and feel free to express themselves. Since this Facebook page of the Douentza group is most actively used by Fulani youth in the diaspora, it connected the Hayre region almost in real time while it was in contact with people living in Bamako, Burkina Faso, Niger, Senegal, Morocco, China, the United States and Europe. The manager of the group is Ibrahima Cisse, a linguist who has studied in Grenoble and at Leiden University. He is from the village of Nokara (next to Douentza) and his family is an established part of the small intellectual elite from the area. There are also members of the Dicko family from Dalla who live in Bamako and are active in these forums. Apart from this, many of the members are students. They discuss the actualities in the region and the manifestations of the crisis. Here there was a connection between mobile phone information that was gained through calls from people from Douentza to people in Bamako who then put this information on the Facebook page. Themes and issues for discussion varied according to the events in the region. For instance, when the MNLA occupied the Hayre, their relationship with the population was discussed. During Opération Serval there was panic on this Facebook page as the telephone lines were down and no connection with the Hayre was possible.

On the 12th of January 2013, there was a discussion between various emigrants from the Douentza area. Their discussion was first about the fact that the phone lines were being blocked in Douentza, Booni, Hombori for security reasons. But initially no one knew who was the instigator of this blocking. Later on, Boukary explains to the other members how interim president Dioncounda Traore had given a speech on national Television the day before about the detrimental impact of rumours that are spread by phone in the fight around Konna. The members than suppose this is why the network in Douentza area went down and continue a small discussion on how indeed, media can have a negative impact on war situations. One of them ends the discussion of that day with the sentence 'Let's pray for our families'. Next day, 13 January 2013, someone informs the group that certain strategic places in the town of Douentza have been bombarded with precision by the French. But apparently, there is not too much panic about it. They finish off by wishing courage to their family members that are now finally freed.

The Facebook group in itself led to new ways of identification, new processes of control, and a revival of belonging for those who had left the area, whether recently or long ago. It was the conflict and the alarming messages coming out of the zone, however, that dramatically intensified the dialogues, connections and interactions online between the rural and urban Fulani worldwide. Interestingly enough, most if not all members seem to feel very secure in this 
Internet and digital environment. Everyone posts his/her comments with full name and pictures, even if they are highly political.

Deental, an association of people from the Hayre who live in Bamako, have informed the diaspora and the intellectuals in the diaspora, through this Facebook page, about their humanitarian actions in the region. Also off line Deental was very active in political lobbying in Bamako in order to get money and humanitarian aid to the region. Their 'crisis committee' coordinated several actions of aid convoys for the Hayre. Since Deental does not have its own website (yet), they used the Douentza group to spread information about their actions.

Apart from this Facebook group, the Internet was used mainly to get news and information about the crisis. Even though this was on a very modest scale and only for those with patience and money to buy airtime, accessing different websites was possible for those in Douentza and Boni with smartphones. In the interviews Boukary carried out in November 2012, several youth indicated that via youth from Bamako who visited their hometowns, they had seen and obtained information from various web- and news sites such as Journal Foufou and Journal Afrique 24. This means that even those youth who do not have telephones themselves benefit from sharing news and items on others' phones, for example Boukary Sangare's phone.

Not only the Internet but also telephone calls played a major role as a source of credible information for the diaspora and those residing in Bamako. Lotte's experience illustrates this importance. When Konna (a small but strategic town near Mopti in Central Mali) was being taken and occupied by the Islamists on 10 January 2013, Lotte called some friends and colleagues who are from this area. ${ }^{22}$ While most of them were residing in Bamako, they explained how they managed to follow 'life' through small films and phone conversations with their family members (cousins, brothers) and friends who had stayed in Konna. So, the youth drinking tea in Bamako paid a lot of airtime to stay online via telephone in order to overhear the gunshot sounds passing through the phones of their friends in Konna. Apart from demonstrating their connectedness, it is also about sharing the emotion of online closeness that allows a form of co-presence.

\section{About the Hayre: The online practice of academia, journalism and war information}

Despite relatively high costs for many (educated) urbanites, accessing the Internet is a daily/weekly reality ever since it became available in its wireless form. The crisis seems to have given a boost to discussing and displaying news online. New journals and newspapers have appeared online, such as Arawane Express, Malijet, Journal du Mali, and Depêches du Mali. Some bloggers, like the academic Bruce Whitehouse with his blog www.bridgesfrombamako.com, have established a reputation and are widely read. Facebook was also an important connector for the urbanites to intellectuals and journalists outside of Mali. Anthropologists living in Mali at the time channelled information in real time by mounting Facebook pages (e.g. 'Americans and friends of Mali' by Stephen Wooten).

Facebook has also become the privileged social network for the upperclass Malians residing both in Mali and/or abroad in the diaspora. This social medium has been used by many groups and individuals to share and discuss information concerning the Mali crisis. Discussion groups 
such as the 'Anti-MNLA', 'Anti-Négociation', 'ATT Alternative', the 'Sofas de la République', 'Journal Foufou', 'Douentza Groupe', and 'Maliden Kura' were created at the outset of the crisis and helped Malians and others to air their frustrations, defend their positions, and learn about those of others (Sangare 2013a, 2013b).

We were ourselves participants in the creation of the news around Mali. We tried to read as many online publications as possible, followed Facebook discussions, and took part in discussions on Internet forums. We published some opinion articles on the Internet, and these publications became sources for the online communities. However, most of the information came from uncorroborated sources and the news creation could be questioned. It is clear that the linkage with people on the ground in these forums was rather flimsy. Some of the experts had never visited the North and based their information on contacts with people in the diaspora and Bamako, who in some instances were linked to people on the ground in the North. Another strategy was to verify information from closed Facebook groups, where information from many sides was moulded into realities that finally entered the newspapers or other circuits of information.

\section{Disconnect}

An example of the creation of such 'flimsy' news is the encounter of Mirjam with a Dutch journalist, who asked her about the situation in the North. Despite the fact that Mirjam had passed on Boukary's contact details, the journalist consulted only the usual circle of main informants; he did not contact Boukary, who had first-hand information, and although the journalist tried to travel to the North, he could not reach beyond Mopti. These experiences filled the Dutch newspapers, and were in themselves interesting stories and analyses, but the foundation of these stories is questionable. The analyses centred on the jihadists and Muslims in the North, whom the journalist never got to meet, and concluded with claims on the broader picture of terrorists in the Sahel.

This example shows the gap between local dynamics and international information circuits. Another example is how the media reported their understanding of the MUJAO. While locally many citizens in the North were in favour of the MUJAO, such local views were not represented in the images portrayed by Western media. On the contrary, in these media, the MUJAO and Ansar Diine were often represented as mere as mere 'bad guys' who engage in Islamic terrorism, cutting off hands, and so on. Many citizens in Douentza were pleased with the arrival of the MUJAO because at least they managed to put an end to the anarchy in the area. The MUJAO was perceived as an organization bringing security rather than violence and threats. Obviously, inhabitants of Douentza did not appreciate all aspects of the MUJAO's policy, such as the strict separation of women and men, for example, in schools, and the fact that youngsters were no longer permitted to listen to their favourite music on their phones. Probably the fact that the MUJAO disposed of a lot of money made their actions more easily accepted. Youngsters who lived together were paid to undergo religious marriages, and cigarette traders were recompensed if they committed to stop trading such illicit and immoral goods. The people who cooperated with the MUJAO were not always ideologically inclined to sharia law; very often they were young and frustrated, but they had finally found among the MUJAO fighters ears that listened to them and hands that fed them. 


\section{DISCUSSION: EMERGING POLITICAL AGENCY IN THE HAYRE}

In his seminal book Smart Mobs (2002), Rheingold established a relationship between access to information and political activism. Others followed his line of reasoning, especially those describing events that were related to what was later labelled in the media the 'Arab spring' (Fahlenbrach et al. 2014a; Zuckerman 2013; www.globaluprisings.org; http://www.warandmedia.org). The Mali case is an example of how this relationship between information and political activism has played out in sub-Saharan Africa. Below we will analyse our presented data. What new networks had been established, and how have old networks intensified both on- and offline during the war in Mali in 2012?

As is clear from the data presented, a new communication landscape emerged in Mali in 2012 due to the increased spread of wireless technology. Information circulated between the on- and offline spaces that increasingly belong to the social spaces the people from the Hayre engage with.

These observations tie in with a general debate on the 'effects' of the new online spaces on sociality in society. The central question in this debate (and in our study) is: how do discussions in both spaces mutually influence each other, and how are they intermingled? In research co-ordinated by Mirjam in Southern, West and Central Africa, the question of the relation between onand offline actions became very visible when in 2010 Chadian youth started to relate to Facebook. Their political ideas were thought to be safe in this space, and they felt free (for the first time) to express themselves politically. However, the concrete consequences are still to be seen (see Seli 2013; de Bruijn et al. 2013). Fahlenbrach et al. (2014b) suggest that political action emerges where the two worlds meet. Others argue that it creates mainly online passivism for example, that it does not lead to political action, but rather to online passivism, also called clicktivism (Cash 2013; Butler 2012). Yet others consider the on- and offline worlds as a single space (see Miller 2013). Georgiadou et al. (2013) add the important element of the activism of the people involved: there needs to be a cause to fight for. Finally, there are those who describe conflicting and varying strands of activism within the online world. This is what Mutsvairo (2013) showed with his thesis on online activism linked to Zimbabwean politics. He observed that online activism led by the diaspora is not much visited by people living in Zimbabwe. Therefore, the calls for action by the diaspora on blogs, online discussion groups and Facebook pages have not materialized on the ground. Other studies show that actions in the offline world have been facilitated by new communication tools. For instance, the possibilities to use the SMS group services of mobile phones did make a difference in the recruitment of people in Nigeria. SMS messages turned the people into a connected online-offline space (see Ekine 2010; Obadare 2006). In the Hayre, both mechanisms are at work. Information flows within the online and offline spaces, and, as we have shown, these spaces meet in some instances and not in others. From the cited studies, we can conclude that there needs to be a connection between on- and offline to enable (effective) political agency to emerge.

The war situation in the Hayre brought new actors and networks to the region. First the MNLA and later the MUJAO took the position of information providers and were also central subjects of information flows. Other existing networks in the Hayre regained momentum during the crisis. Such was the case for the Fulani families who have been dispersed owing to the conflict. 
Although mobility and dispersal is a phenomenon that is familiar to the Fulani nomads, it was exacerbated on an involuntary basis by the conflict and insecurity made more people leave the region in search of safer pastures.

Early in 2012 the usual information network that consisted of administrators and civil servants disappeared when they left the region out of fear of the 'rebel' groups. It was more or less replaced by another network, namely, that of academics, intellectuals and journalists, but also the diaspora members in Bamako, who gathered and exchanged in cyberspace. These networks have varying levels of access to new media and also have a different capability to use them. The Fulani herders are connected by mobile phone, as are the MUJAO, who can opt out and retreat into regions without wireless connectivity (for now). The academics/journalists have a significant online presence, but they lack an offline presence on the ground; it is the group of Hayrankoobe who live in Bamako and further away who have both online connections with the people in the Hayre through the Internet (Facebook) and offline connections through direct exchanges of travellers and via mobile phone. These circles overlap. Probably the most remarkable are the intersections between Fulani herdsmen and the MUJAO (also via film), and the overlap between Fulani urban youth and the diaspora/Bamako Fulani (an example was the Deental group and the Facebook groups [Douentza]). The networks and their intersections are represented in Figure 2.

If we apply the hypothesis formulated above suggesting that most political action takes place where the different forms of information networks meet, i.e. off and online, for our case this would mean that the Deental group has increased its political potential as activists for development of the Hayre region thanks to online exchanges. Indeed, the interconnection created on Facebook, integrated with information gathered through mobile phone contacts, was the direct reason for the emergence of Deental as an action group. Its strength, however, also relied on the grounding of this group in connection between the members, based on ethnicity and geographical attachment. Both Fulaniness and the Hayre were the important markers to make it work. Ties through family, friendship, and ethnicity were those of the past, but they regained momentum in this period and with the possibilities to connect.

The meeting of Fulani nomads and the MUJAO in the mobile phone on/offline space and offline also created a new linkage. The Fulani herdsmen were triggered by the absence of the state and by their experience of being neglected/marginalized to embrace the new ideology and actions of the MUJAO. They sent their children to the (offline) training camps and in general were positive about these new actors in their region. Watching the PR videos and listening to the preaching of the leaders reinforced their shared identity in Islam but foremost their common 'hatred' for the Malian government and state services. They, of course, were also triggered by the economic benefits and the simple fact that they experienced a certain form of security, both very much offline experiences. It is interesting to realize that the disconnected circle, the online group of intellectuals and diaspora, live in their own world, where a completely different interpretation was presented of the Fulani herdsmen who moved towards the MUJAO. It must be admitted that this online community had many of the characteristics of a bubble. It is disappointing to realize that analysts in policy circles and among journalists, and also intellectuals and academic researchers, are all largely dependent on this kind of 'information bubble' when they find themselves faced with a locale 


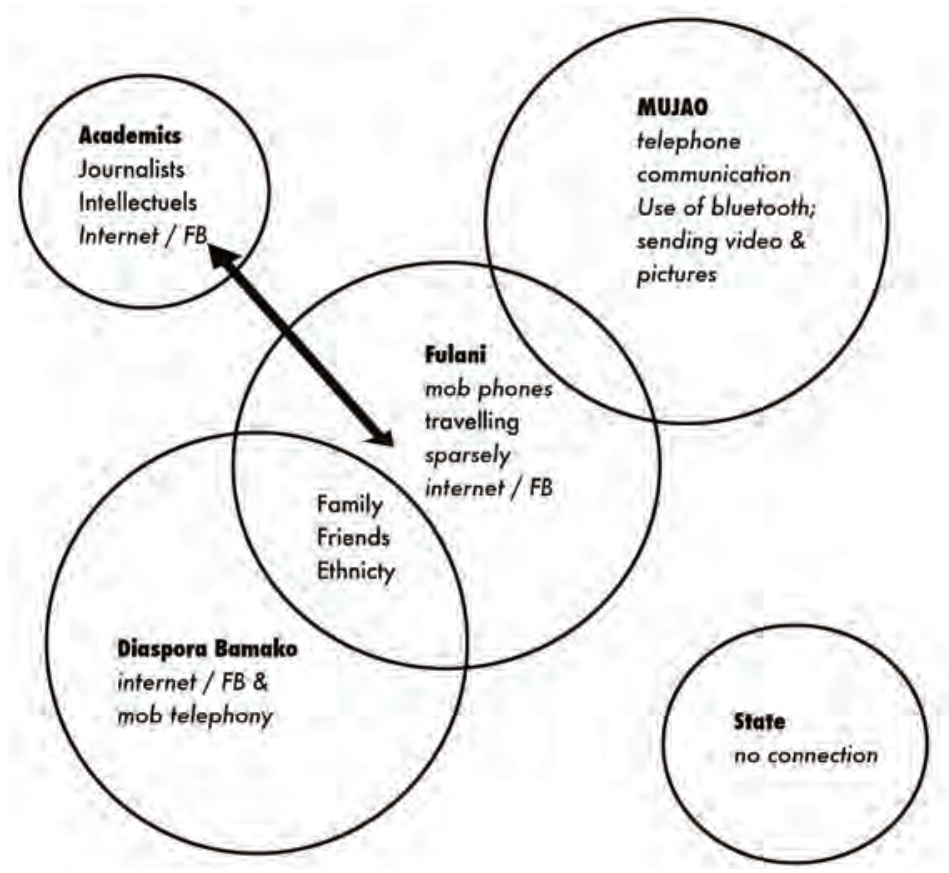

Figure 2: Information Circuits: (dis)connected on-and off-line networks.

that has been turned into a war situation and when it is simply too dangerous to go into the area and work on the ground.

To conclude: Does new political agency emerge in the interplay between new ICT and war dynamics? In the case of the Hayre, we have seen new information flows emerging and intensification of existing networks with new information content; outside the Hayre the diaspora/migrants have found new activities and recreated their linkage with their Hayre or Fulani identity/ethnicity. New information networks do emerge, both on- and offline. They become sources of information, and they are based on an urge from the network participants to receive information in order to fight for the cause they (re)define. It would require another article to show how the online information created in the bubble of journalists, academics and groups in the diaspora feed into other information circles, circles that then create the news. If these newly appearing networks, or lineages between networks, based on older forms do also lead to political agency we cannot answer on the basis of the analysis of the year 2012 alone. This would require a follow-up of political actions in the region. However, we can say that the potential for new actions is present.

In this article we focused on the creation of new information networks around the Fulani nomads and urban youth and how these connected to both on- and offline news networks with the MUJAO and in urbanites outside the Hayre, in the south of Mali and in some West African countries. These interrelated networks of on- and offline information flows created a new space for nomads and youth to (re)invent their political agency. The interactivity of media (Hepp 2013) and the combination of different ICTs (Madianou and Miller 2012) are part of the explanation, but it is foremost 
the possibilities that new ICTs offer to the communication space of the Hayrankoobe and the decisions of the Hayrankoobe to engage with these media - because they had/have a cause to fight for - that has been decisive in this process. Both urban youth and nomads seem to follow their histories of networking and communication in a space that was stimulated by the war environment. The way they integrate new information flows into the practice of their political agency is an intriguing process that should be followed in the coming years.

\section{ACKNOWLEDGEMENTS}

We wish to thank Jacky Boujou, Shamil Jeppie, and the team of Connecting in Times of Duress for their comments and suggestions.

The research for this article is based on a research programme based at Leiden University: www.connecting-in-times-of-duress.nl, funded by NWO, project number W0170600 001.

\section{REFERENCES}

Ag Rissa, Y. (2009), 'Mobilité et téléphone portable en milieu Tamashaq du Mali: usages et appropriations chez les Kel Adagh', Mémoire de Maîtrise: Anthropologie, FLASH, Mali: Université de Bamako .

Anon. (2012a), 'Les islamistes prennent le contrôle de la ville de Douentza, dans le sud du pays', Jeune Afrique, 1 September, http://www.jeuneafrique. com/Article/ARTJAWEB20120901134559/. Accessed 20 October 2014.

- (2012b), 'Les-islamistes-prennent-le-controle-de-la-ville-de-douentzadans-le-sud-du-pays', Jeune Afrique, 1 September, http://www.jeuneafrique. com/Article/ARTJAWEB20120901134559/mali-aqmi-islamiste-nord-malimali-les-islamistes-prennent-le-controle-de-la-ville-de-douentza-dansle-sud-du-pays.html. Accessed 20 October 2014.

_ (2012c), 'Mali, un animateur de Radio battu par les islamistes hospitalisée a Gao', Slate Afrique, 6 August, http://www.slateafrique.com/92361/ mali-un-animateur-de-radio-battu-par-les-islamistes-hospitalise-gao. Accessed 20 October 2014.

_ (2012d), 'Nord-Mali: un animateur radio hospitalisé à Gao après avoir été tabassé par le MUJAO', Jeune Afrique, 6 August, http://www.jeuneafrique.com/Article/ARTJAWEB20120806151112/. Accessed 20 October 2014.

_ (2013), 'Mali: le front anti-putsch réclame "sans délai" l'intervention d'une force africaine', Jeune Afrique, 4 September, http://www.jeuneafrique.com/actu/20120904T122319Z20120904T122317Z/\#ixzz25bc0bgju. Accessed 20 October 2014.

Bøås, M. (2012), 'Castles in the sand: Informal networks and power brokers in the Northern Mali periphery', in M. Utas (ed.), African Conflict and Informal Power: Big Me and Networks, London: Zed Books, pp. 119-34.

Bøås, M. and Torheim, L.-E. (2013), 'The trouble in Mali: Corruption, collusion, resistance', Third World Quarterly, 34: 7, pp. 1279-92.

Bonnecase, V. and Brachet, J. (2013), 'Les « crises sahéliennes » entre perceptions locales et gestions internationales', Politique Africaine, 130, Le Dossier "Crises et chuchotements au Sahel", pp. 5-22.

Butler, M. (2012), Clicktivism, Slacktivism, or 'Real' Activism Cultural Codes of American Activism in the Internet Era, ProQuest, UMI Dissertation Publishing. 
Cash, J. (2013), 'The rise of clicktocracy: Politics for a digital age', lulu.com, 5 September. Accessed 23 September 2014.

Castells, M. (2009), Communication Power, Oxford: Oxford University Press.

Chabal, P. (2009), Africa: The Politics of Suffering and Smiling, London and New York: Zed Books.

Cold-Ravnkilde, S. M. (2013), 'War and peace in Mali: Background and perspectives', Diis report, number 33, http://en.diis.dk/files/publications/ Reports2013/RP2013-33_MALI-Signe-marie-cold-ravnkilde_web.pdf. Accessed 15 February 2014.

De Bruijn, M. E. (2007), 'Mobility and society in the Sahel: An exploration of mobile margins and global governance', in H. Hahn and G. Klute (eds), Cultures of Migration, Munster: Lit Verlag, pp. 109-29.

De Bruijn, M. and van Dijk, H. (1995), Arid Ways, Cultural Understandings of Insecurity in Fulbe Society, Central Mali, Amsterdam: Thela Publishers.

De Bruijn, M. et al. (2013), Side@Ways: Mobile Margins and the Dynamics of Communication in Africa, Leiden, Bamenda: ASC and Langaa.

De Bruijn, M. E. and Sangare, B. (2012), 'La zone frontalière avec la supposée "République de l'Azawad"', http://www.tombouctoumanuscripts. org/db/entry/la_zone_frontaliere_avec_la_supposee_republique_de_ lazawad_/ (published 6 June on Tombouctou manuscripts (UCT) Afrique du Sud) and also on ASC website, http://www.ascleiden.nl/sites/default/ files/Azawad\%20_2_.pdf.

Ekine, S. (ed.) (2010), SMS Uprising: Mobile Activism in Africa, Pambazuka Press.

Fahlenbrach, K., Sivertsen E. and Werenskjold, R. (eds) (2014a), Media and Revolt, Strategies and Performances from the 1960s to the Present, New York and Oxford: Berghahn Books.

— (2014b), 'Introduction: Media and protest movements', in Media and Revolt, Strategies and Performances from the 1960s to the Present, New York and Oxford: Berghahn Books, pp. 1-19.

Gavelle, J., Siméant, J. and Traore, L. (2013), 'Le court terme de la légitimité: prises de position, rumeurs et perceptions entre janvier et septembre 2012 à Bamako', Politique Africaine, 130, Le Dossier 'Crises et chuchotements au Sahel', pp. 23-46.

Gleick, J. (2011), The Information: A History, a Theory, a Flood, New York: Pantheon Books.

Gary-Tounkara, D. (2013), 'La gestion des migrations de retour, un paramètre négligé de la grille d'analyse de la crise malienne', Politique Africaine, 130, Le Dossier 'Crises et chuchotements au Sahel', pp. 47-68.

Georgiadou, Y., Lungo, J. H. and Richter, C. (2013), 'Citizen sensors or extreme publics? Transparency and accountability interventions on the mobile geoweb', International Journal of Digital Earth, http://dx.doi.org/ 10.1080/17538947.2013.782073.

Hagberg, S. and Körling G. (2012), 'Socio-political turmoil in Mali: the public debate following the coup d'état on March 2012', Afrika Spectrum, 2-3, pp. 111-126.

Hepp, A. (2013), Cultures of Mediatization, Cambridge: Polity Press.

Hine, C. (2000), Virtual Ethnography, London: Sage Publications, http://cyberanthropology.wordpress.com/tag/christine-hine/. Accessed 15 April 2014.

Horst, H. and Miller, J. (2012), Digital Anthropology, London and New York: Berg Publishers. 
Keita, N. (2013a), 'Grandeur ou misères des cabines téléphoniques privées et publiques au Mali', in M. De Bruijn (eds), Side@Ways: Mobile Margins and the Dynamics of Communication in Africa, Leiden, Bamenda: ASC andLangaa, pp. 129-58.

_ (2013b), 'Més(usages) et tendances récentes en matière de communication au Mali : le « pouvoir » du téléphone portable en «temps de crise', unpublished conference paper, CAAS Conference, Ottowa, Canada, 1-5 May.

Lacher, W. and Tull, D. M. (2013), 'Mali: Beyond counterterrorism', German Institute for International and Security Affairs, http://www.swp-berlin.org/ en/scientist-detail/ profile/wolfram_lacher.html. Accessed 20 March 2014.

Lecocq, B. et al. (2013), "The blind and the hippopotamus: A multivocal analysis of the current political crisis in the divided republic of Mali', Review of African Political Economy, 137, pp. 343-57.

Madianou, M. and Miller, D. (2012), Migration and New Media: Transnational Families and Polymedia, London: Routledge.

Maliweb (2012a), 'Nouveau bilan: 30 Burkinabés tues a la frontière avec le Mali dans des violences', Maliweb, 25 May, http://www.maliweb.net/news/ faits-divers/2012/05/25/article,69147.html. Accessed 20 October 2014.

- (2012b), 'Mali: Aux armes les citoyens!', Maliweb, 8 August, http://www. maliweb.net/news/insecurite/2012/08/08/article,85002.html. Accessed 20 October 2014.

— (2012c), 'Edito: Les Islamistes vers Bamako?', Maliweb, 3 September, http://www.maliweb.net/news/la-situation-politique-et-securitaireau-nord/2012/09/03/article,89102.html. Accessed 20 October 2014.

(2012c), 'Occupation de Douentza: Une tendance de Ganda Izo en cause', 6 September, Maliweb, http://www.maliweb.net/news/la-situationpolitique-et-securitaire-au-nord/2012/09/06/article,90008.html. Accessed 20 October 2014.

Miller, D. (2013), Tales from Facebook, Cambridge: Polity Press.

Mutsvairo, B. (2013), 'Power and participatory politics in the digital age, probing the use of new media technologies in railroading political changes in Zimbabwe', Ph.D. dissertation, Leiden University.

Obadare, E. (2006), 'Playing politics with the mobile phone in Nigeria: Civil society, big business and the state', Review of African Political Economy, 33: 107, pp. 93-111.

Pelckmans, L. (2009), 'Phoning anthropologists: The mobile phone's (re-)shaping of anthropological research', in M. E. de Bruijn, F. Nyamnjoh and I. Brinkman (eds), Mobile Phones: The New Talking Drums of Everyday Africa, Bamenda, Leiden: Langaa and ASC, pp. 23-49.

(2011), 'Travelling hierarchies: Moving in and out of slave status in a Central Malian Fulбe network', African Studies collection, 34, Leiden: ASC.

— (2013), 'Moving memories of slavery among West African migrants in urban contexts (Bamako, Paris)', European Journal of International Migration, 29: 1, pp. 45-68.

- (2015), Intra-ethnic fragmentation and the emergence of new (in-)security actors in Mali, in DIIS Report 2015:01 'Protection and (in)security beyond the state: insights from Eastern Africa and the Sahel', pp. 43-58, http:// www.diis.dk/node/4814.

RFI (2012a), 'Mali: le MNLA \& Ansar Dine fusionnent', RFI, 27 May, http:// www.rfi.fr/afrique/20120527-mali-mnla-ansar-dine-charia-azawad-coran. Accessed 20 October 2014. 
(2012b), 'Islamistes-mujao-avancent-vers-le-sud-pays-s-emparentdouentza', RFI, 1 September, http://www.rfi.fr/afrique/20120901-maliislamistes-mujao-avancent-vers-le-sud-pays-s-emparent-douentza. Accessed 20 October 2014.

- (2012c), 'Mali: les nouveaux maîtres de Douentza restent discrets', 4 September, RFI, http://www.rfi.fr/afrique/20120904-mali-nouveauxmaitres-dounetza-restent-discrets/. Accessed 20 October 2014.

Rheingold, H. (2002), Smart Mobs, The Next Social Revolutions, Transforming Cultures and Communities in the Age of Instant Access, Cambridge: Basic Books.

Sangare, B. (2009), 'Peuls et Mobilité dans le cercle de Douentza: l'espace social et la téléphonie mobile en question', Mémoire de Maîtrise: Anthropologie, FLASH, Mali: Université de Bamako.

— (2012a), 'Les rebelles séduisent les maliens du Nord', http://www.rnw. nl/afrique/article/les-rebelles-s\% C3\%A9duisent-les-maliens-du-nord, (published 18 May 2012 on Radio Netherlands Worldwide (RNW).

_-(2012b), 'Lesjeunes de Douentza prennentleurdestin en main', http://www. rnw.nl/afrique/article/les-jeunes-de-douentza-prennent-leur-destinen-main, (published 13 June 2012 on Radio Netherlands Worldwide (RNW).

- (2012c), 'Douentza sous occupation des rebelles du MNLA: conséquences sur la vie quotidienne des populations- première série', http://www.ascleiden.nl/?q=content/douentza-sous-occupation-des-rebelles-du-mnlapremi\%C3\%A8re-s\%C3\%A9rie, (published 2 July 2012 on homepage of the African Studies Centre, Leiden, The Netherlands).

- (2013a), 'Réseaux sociaux et communication en temps de crises au Mali: l'exemple des groupes de discussion sur Facebook', in ECAS 2013, 5th European Conference on African Studies 'African Dynamics in Multipolar World', Lisboa: CEI, 2014. 978-989-732-364-5. pp. 1918-42.

- (2013b), 'Conflit au Nord du Mali et Dynamiques sociales chez les peuls du Hayré', Mémoire de Master: Sociologie, FLSH, Université Cheikh Anta Diop de Dakar, Sénégal.

Seli, D. (2013), (Dé)connexions identitaires Hadjeray: Les enjeux des technologies de la communication au Tchad, Leiden, Bamenda: ASC/Langaa. The War and Media Network, http://www.warandmedia.org/. Accessed 20 October 2014.

Underberg, N. M. and Zorn, E. (2013), Digital Ethnography: Anthropology, Narrative and New Media, Texas: University of Texas Press, https://utpress. utexas.edu/index.php/books/unddig\#sthash.zAnbhWa1.dpuf.

Unesco, http://www.unesco.org/new/en/mediaservices/singleview/news/ damage_to_timbuktus_cultural_heritage_worse_than_first_estimated_ reports_unesco_mission/\#.U7KF0rGYp8R. Accessed 20 October 2014.

Wasserman, H. (2011), Popular Media, Democracy and Development in Africa, London [etc.]: Routledge.

Zuckerman, E. (2013), Rewire: Digital Cosmopolitans in the Age of Connection, London and New York: W.W. Northon \& Company Inc.

\section{SUGGESTED CITATION}

Bruijn, M. de, Pelckmans, L. and Sangaré, B. (2015), 'Communicating war in Mali, 2012: On-offline networked political agency in times of conflict', Journal of African Media Studies, 7: 2, pp. 109-128, doi: 10.1386/jams.7.2.109_1 


\section{CONTRIBUTOR DETAILS}

Mirjam de Bruijn is Professor of Anthropology and Contemporary History of Africa at Leiden University and researcher at the African Studies Centre, Leiden, The Netherlands. Her work has a clearly interdisciplinary character and concentrates on West and Central Africa. She focuses on the interrelationship between agency, marginality, mobility, connectivity and communication. An important theme throughout is how people manage risk (drought, war, etc.) in both rural and urban areas. From 2008 to 2013 she was co-ordinating the research programme 'Mobile Africa Revisited' (mobileafricarevisited.wordpress.com), a comparative study of the role of Information and Communication Technologies (ICT) and ICT's interrelationship with agency, marginality and mobility patterns in Central and West Africa. In 2012 Mirjam was awarded a Vici grant (NWO), 'Connecting in Times of Duress: Understanding Communication and Conflict in Middle Africa's Mobile Margins' (www.connecting-in-times-of-duress.nl). Recently she started a new project, Voice4Thought, in which the voices of changing agents are central (www.voice4thought.org).

Contact: Institute for History, Leiden University; PO Box 9515, 2300 RA Leiden, The Netherlands.

E-mail: m.e.de.bruijn@hum.leidenuniv.nl

Lotte Pelckmans is a researcher at DIIS, and specialized in global issues related to human rights, inequality, migration, slavery, social movements and media in (conflict areas) in West and Central Africa. She recently started working on youth, security, radicalisation and terrorism in the Sahel region, with a focus on Mali, Niger and Nigeria. Her Ph.D. research (2005-2009) at the African Studies Centre in Leiden resulted in a book entitled 'Travelling Hierarchies: Moving in and out of slave status in a central Malian Fulbe Network'. This book analyses the maintenance of hierarchical relations inherited from the slave past among Fulbe migrants in Mali. It points to important connections between mobility, slavery, hierarchy and multiple identities in West Africa. Between 2010 and 2011 she was assistant professor (UD2) at Nijmegen University, teaching on Migration, Multiculturalism, Qualitative Research Methods and Ethnography. In 2012 she worked on postdoctoral research at the Centre d'études Africaines (Ecole des Hautes Etudes en Sciences Sociales), thanks to the European COFUND Fernand Braudel Grant of the 'Maison des Sciences de l'Homme' in Paris. From 2013 onwards Lotte was based at the Leiden Institute of History (Netherlands) where she pursued postdoctoral work on the modern history of conflict, social media and mobility in Central African countries (North Cameroon, Chad, Nigeria and Central African Republic) (see the Connecting in Times of Duress Programme website). In December 2014, she started working for the Danish Institute for International Studies, in Copenhagen, Denmark. www.diis.dk

Contact: Dansk Institut for Internationale Studier, Østbanegade 117, 2100 København Ø, Danmark.

E-mail: lpel@diis.dk

Boukary Sangaré is a Ph.D. student at Leiden University and The University of Cheikh Anta Diop at Dakar (since 2013). The title of his project is 'Les Peuls du nord Mali face aux crises 'Sahéliennes': Entre protectionnisme, conflictualités 
internes et radicalisation'. He has worked on several evaluation and consultancy studies (with ARGA-Mali, IRPAD-Afrique and ODHD/LCP) on diverse themes: governance, security, social welfare, poverty, inequality and gender. His key publications include 'Réseaux sociaux et communication en temps de crises au Mali : l'exemple des groupes de discussion sur facebook' in ECAS 2013, 5th European Conference on African Studies 'African Dynamics in Multipolar World'. Lisboa: CEI, 2014. 978-989-732-364-5. p. 1918-1942 and Sangare, B. \& Dakouo, A. and 'Gouvernance et stratégies foncières locales dans les communes de Kendié et de Ber' in: Ambroise Dakouo \& Modibo Keita (dir), Gouvernance participative et Pratiques Démocratiques au Mali, Paris \& Bamako: Harmattan/Sahélienne, Avril 2013, pp. 128-140.

Contact: Institute for History, Leiden University; PO Box 9515, 2300 RA Leiden, The Netherlands.

E-mail: boukarysangare@gmail.com/b.sangare@umail.leidenuniv.nl.

Mirjam de Bruijn, Lotte Pelckmans and Boukary Sangare have asserted their right under the Copyright, Designs and Patents Act, 1988, to be identified as the authors of this work in the format that was submitted to Intellect Ltd. 